\title{
CITRA PEREMPUAN JAWA DALAM NOVEL HATI SINDEN KARYA DWI RAHYUNINGSIH: KAJIAN FEMINISME LIBERAL
}

\author{
Nur Fitriani ${ }^{\bowtie}$, U’um Qomariyah, Sumartini \\ Jurusan Bahasa dan Sastra Indonesia, Fakultas Bahasa dan Seni, Universitas Negeri Semarang, \\ Indonesia
}

\section{Info Artikel}

Sejarah Artikel:

Diterima Oktober 2017

Disetujui Desember 2017

Dipublikasikan Maret

2018

Keywords:

women image; javanese women; liberal feminism

\begin{abstract}
Abstrak
Masyarakat Jawa memiliki prinsip-prinsip dasar tentang sikap batin yang tepat, yaitu terkontrol, tenang, berkepala dingin, sabar, halus, tenggang rasa, bersikap sederhana, jujur, sumarah, halus, dan tidak mengejar kepentingan diri sendiri. Perempuan Jawa sering dianggap lebih rendah derajatnya dari kaum lelaki. Sikapnya yang lebih pasif, lemah lembut, dan sebagainya sering dianalogikan bahwa perempuan adalah makhluk yang lemah. Sumber data penelitian ini adalah novel Hati Sinden karya Dwi Rahyuningsih yang diterbitkan oleh Diva Press pada tahun 2011. Metode penelitian yang digunakan adalah deskriptif-kualitatif dengan pendekatan feminisme. Penelitian ini difokuskan pada citra perempuan Jawa tokoh utama perempuan dan upaya mempertahankan citra perempuan Jawa pada tokoh utama perempuan. Data diperoleh dengan menggunakan teknik baca-catat. Hasil penelitian ini menunjukkan bahwa: 1) citra perempuan Jawa yang ada dalam diri tokoh utama perempuan berupa sifat nrima, sabar, pasrah, lembut, bakti, dan pandai berhemat. Selain itu, tokoh utama perempuan juga memiliki perhatian terhadap orang lain dan pengendalian diri tinggi. 2) tokoh utama perempuan mempertahankan citra perempuan Jawa dalam novel ini sebagai upaya menyetarakan kedudukan antara laki-laki dan perempuan di dalam masyarakat.. Tindakan tokoh utama perempuan dalam mempertahankan citra perempuan Jawa merupakan salah satu upaya untuk menyetarakan perempuan di dalam ruang lingkup masyarakat Jawa.
\end{abstract}

\section{Abstract}

The Javanese people have basic principles of proper inner attitude, controlled, calm, level-headed, patient, subtle, tolerant, simple, honest, summarized, refined, and self-pursuing. Javanese women are often thought to be lower in rank than men. His attitude is more passive, gentle, and so it is often analogized that women are weak creatures. The source of this research is by Dwi Rahyuningsih's novel entitled Hati Sinden published by Diva Press on 2011. The method that this research used is descriptivequantitative with literature feminism approach. This research is focusing on Javanese women's image and how the female character herself struggling to sustain image of Javanese women. The method that this research used is descriptive-quantitative with literature feminism approach. This research is focusing on Javanese women's image and how the female character herself struggling to sustain image of Javanese women. The data are obtained using a reading-record technique. The results of the analysis of this study are as follows. 1) image of Javanese women that exist in the female main character can be concluded that the criteria of Javanese women as female figure who is supposed to 
Nur Fitriani / Jurnal Sastra Indonesia 7 (1) (2018)

be borne, patient, resigned, gentle, devoted, and frugal. 2) The main character's struggles to sustain the image of Javanese women can be concluded that Sayem's life in community gives an impact to her image.

(C) 2018 Universitas Negeri Semarang

Alamat korespondensi:

ISSN 2252-6315

Gedung B1 Lantai 1 FBS Unnes

Kampus Sekaran, Gunungpati, Semarang, 50229

E-mail: nurfitriani02@gmail.com 


\section{PENDAHULUAN}

Para tokoh perempuan selalu mengalami penderitaan yang sebagian besar dikarenakan ketidakberdayaan mereka terhadap aturan-aturan tradisi yang telah melekat pada sebagian besar masyarakat di indonesia. masyarakat jawa memiliki prinsip-prinsip dasar tentang sikap batin yang tepat, yaitu terkontrol, tenang, berkepala dingin, sabar, halus, tenggang rasa, bersikap sederhana, jujur, sumarah, halus, dan tidak mengejar kepentingan diri sendiri. perempuan jawa sering dianggap lebih rendah derajatnya dari kaum lelaki. sikapnya yang lebih pasif, lemah lembut, dan sebagainya sering dianalogikan bahwa perempuan adalah makhluk yang lemah. dalam masyarakat, buruh perempuan lebih dianggap lemah dan memiliki pekerjaan yang tidak memerlukan banyak tenaga. buruh laki-laki dianggap kuat dan memiliki pekerjaan yang cenderung lebih memerlukan banyak tenaga. hal tersebut mengisyaratkan bahwa perempuan berderajat lebih rendah dibanding laki-laki. serta eksistensi perempuan lebih banyak didominasi oleh kekuatan budaya, adat istiadat, dan aturanaturan yang berlaku.

Citra perempuan merupakan sebuah gambaran dalam realita kehidupan. Kehidupan dalam hal ini adalah kehidupan tokoh Sayem dalam novel yang mendeskripsikaan sosok perempan Jawa. Karakter tokoh utama sangat relevan bila dianalisis dengan feminisme liberal. Berdasarkan masalah dalam penelitian ini, penulis tertarik untuk meneliti citra perempuan Jawa dalam novel Hati Sinden dengan kajian feminisme liberal.

Novel Hati Sinden karya Dwi Rahyuningsih merupakan salah satu novel yang di dalamnya terdapat citra perempuan pada tokoh utama di dalam ruang lingkup kehidupan masyarakat Jawa. Dalam novel Hati Sinden, pengarang memunculkan berbagai citra perempuan Jawa dalam kehidupan tokoh utama perempuan. Selain itu, pengarang juga menggambarkan perlawanan tokoh utama dalam ketidakadilan gender dan melakukan pengorbanan untuk menyetarakan kedudukan antara laki-laki dan perempuan.

Dalam penelitian ini, rumusan masalah yang dibahas mengenai: 1) gambaran citra perempuan Jawa yang ada dalam diri tokoh utama perempuan; 2) upaya tokoh utama perempuan dalam mempertahankan citra perempuan Jawa. Tujuan dalam penelitian ini adalah untuk memperoleh jawaban dari rumusan masalah yang telah dipaparkan sebelumnya. Dari rumusan masalah itulah peneliti bertujuan ingin menunjukkan melalui karya sastra yaitu novel Hati Sinden dapat memberikan penyadaran terhadap masyarakat tentang bentuk citra perempuan Jawa yang begitu penting untuk kaum perempuan. Penelitian ini juga diharapkan mampu memotivasi para perempuan untuk terus melawan ketidakadilan gender yang membelenggu mereka dan senantiasa menjaga citra perempuan dari sifat maupun sikap perempuan zaman sekarang yang semakin tidak memedulikan citranya agar terhindar dari ketidakadilan gender.

Adapun manfaat dari penelitian ini adalah dapat memberikan sumbangan pemikiran dan keilmuan bagi khazanah penelitian sastra di Indonesia, khususnya dalam kajian prosa berupa novel; memberikan 
wawasan dan proses pembelajaran bagi peneliti dalam mengkaji karya sastra menguntukkan pendekatan feminisme sastra; hasil penelitian ini dapat menjadi acuan bagi peneliti lain yang akan meneliti novel Hati Sinden karya Dwi Rahyuningsih ataupun novel lain dengan tema sejenis; bagi masyarakat secara umum, penelitian ini dapat memberikan pengetahuan tentang bentuk citra perempuan Jawa yang sekarang mulai tidak di perhatikan dalam masyarakat indonesia terutama masyarakat Jawa; penelitian ini juga menjadi upaya perempuan melawan ketidakadilan gender untuk menyetarakan hak perempuan di masyarakat.

Analisis yang pertama dilakukan dalam penelitian ini adalah mencari bentuk citra perempuan Jawa yang ada dalam tokoh utama perempuan. Perempuan dalam konvensi budaya Jawa digambarkan dalam berbagai sifat. Sifatsifat nrima, pasrah, sabar, halus, setia, bakti, masih merupakan ciri khas yang ideal mengenai perempuan Jawa. Sifat-sifat seperti ini memang sering tercermin dalam perempuan Jawa pada umumnya. Namun demikian tetaplah merupakan sesuatu yang terbentuk karena lingkungan dan keadaaan. Sifat nrima dan pasrah yang sering menjadi ciri khas dari perempuan Jawa ini merupakan hal yang membuatnya mampu bertahan dalam menghadapi berbagai kesulitan hidupnya. Nrima dan pasrah bukan berarti tidak berusaha, tetapi berusaha mengatasi kesulitan dan secara sadar mampu untuk menerima keadaan dan pasrah pada nasibnya, apabila sesuatu keadaan tidak dapat diubah lagi. Hal tersebut diperkuat dengan pernyataan Handayani dan Novianto
(2004: 130) mengatakan bahwa karakter perempuan Jawa sangat identik dengan kultur Jawa, seperti bertutur kata halus, tenang, diam/kalem, tidak suka konflik, mementingkan harmoni, menjunjung tinggi nilai keluarga, mampu mengerti dan mamahami orang lain, sopan, pengendalian diri tinggi/ terkontrol, memegang peranan secara ekonomi, dan setia atau loyalitas tinggi.

Penelitian ini pada dasarnya mengkaji hubungan karya sastra dan keadaan yang dialami perempuan. Dalam keberagaman analisis karya sastra menguntukkan disiplin feminisme, feminisme liberal diuntukkan peneliti karena relevan dengan permasalahan yang dikaji. Susanto (2016) berpendapat bahwa manusia adalah otonom dan dipimpin oleh akal (reason). Melalui akalnya, manusia mampu memahami prinsip-prinsip moralitas, nilai, kebebasan individu. Prinsip ini menjamin hak individu. Perempuan terletak pada tidak adanya hak yang sama, untuk memajukan dirinya dan peluang pembudayaan yang sama.

$$
\text { Feminisme liberal merupakan }
$$
pandangan untuk menempatkan perempuan yang memiliki kebebasan secara penuh dan individual. Kebebasan dan keseimbangan berakar pada rasionalitas, pada dasarnya tidak ada beda antara laki-laki dan perempuan perjuangan kaum ini menuntut kesempatan dan hak yang sama bagi setiap individu termasuk perempuan atas dasar kesamaan keberadaannya sebagai makhluk sosial. Usaha perempuan untuk bisa setara dengan laki-laki dalam berbagai aspek atas kemauan untuk memuaskan dirinya sendiri dan tidak bergantung lagi pada pria. Selain itu, diuntukkan juga ilmu sosial 
tentang masyarakat untuk membantu mengupas citra perempuan yang ada dalam diri tokoh utama perempuan dari sudut pandang feminis.

Teori feminisme liberal diuntukkan karena sesuai dengan objek penelitian yang diambil yaitu mengenai tokoh perempuan.

Suatu penelitian memerlukan keaslian sehingga penelitian terdahulu yang relevan dapat dijadikan kajian pustaka dalam penelitian ini. Oleh karena itu, penelitian memerlukan tinjauan pustaka. Tinjauan penelitian yang berkaitan dengan feminisme dalam penelitian ini diantaranya adalah: Yuliastuti (2005), Fraser (2007), Mandarastuty (2010), Agustin (2013), Rejeki (2013), Syafrima (2013), Nurhayati (2014), Rini (2014), Bell (2016).

\section{METODE PENELITIAN}

Metode yang diuntukkan dalam penelitian ini adalah deskriptif kualitatif dengan cara melukiskan data dan analisis dalam feminisme sastra. Sedangkan pendekatan dalam penelitian ini adalah feminisme liberal. Data dalam penelitian ini yakni teks dalam novel Hati Sinden karya Dwi Rahyuningsih yang mengandung unsur watak tokoh, pemikiran tokoh, tindakan tokoh, dan percakapan antar tokoh serta ulasan-ulasan mengenai novel Hati Sinden baik berupa buku, artikel, maupun internet. Adapun teknik pengumpulan data yang diuntukkan dalam penelitian ini adalah bacacatat.

\section{HASIL PENELITIAN DAN PEMBAHASAN}

Gambaran Citra Perempuan Jawa pada Tokoh Utama Perempuan
Dalam penelitian ini, dilakukan analisis terhadap citra perempuan Jawa yang dialami tokoh utama perempuan melalui tindakan tokoh, pemikiran tokoh, percakapan antar tokoh, maupun cerita dari sudut pandang tokoh utama yang berkaitan dengan citra perempuan Jawa. Peneliti mencari data yang menunjukkan gambaran citra perempuan dengan membaca dan mencatat data yang menggambarkan citra. Setelah membaca dan mencatat kutipan novel yang berhubungan dengan citra, peneliti mengdeskripsikan kutipankutipan tersebut. Banyak data yang menggambarkan citra perempuan Jawa pada tokoh utama perempuan berupa digambarkan dalam berbagai sifat. Sifat-sifat nrima, sabar, pasrah, lembuh, dan pandai berhemat masih merupakan ciri khas yang ideal mengenai perempuan Jawa. Selain itu, karakter perempuan Jawa sangat identik dengan kultur Jawa, seperti bertutur kata halus, tenang, diam/kalem, tidak suka konflik, mementingkan harmoni, menjunjung tinggi nilai keluarga, mampu mengerti dan mamahami orang lain, sopan, pengendalian diri tinggi/ terkontrol, memegang peranan secara ekonomi, dan setia atau loyalitas tinggi. Sifat-sifat seperti ini memang sering tercermin dalam perempuan Jawa pada umumnya.

Sayem memiliki sifat lembut seperti perempuan Jawa lainnya. Menurut kriteria lima pancadan: Perempuan kedah ririh, ruruh, rereh (perempuan hendaknya melatih kelembutan, kestabilan emosi, keteduhan sikap, dan tenang dikala menghadapi segala problema). Kelembutan yang telah dimiliki telah melekat sebagai identik dari perempuan Jawa. Terbukti pada kutipan berikut. 
Mbak Parti seorang perempuan yang berperilaku baik, lembut, dan mengasihi teman. Darinya, aku bisa belajar banyak tentang sikap perempuan yang santun. Pergaulanku dengan teman-teman sinden, sedikit banyak berpengaruh pada cara perpikirku. Ternyata, perempuan diciptakan dengan watak yang berbeda-beda. (HS: hal 223)

Kutipan di atas menunjukkan bahwa kelembutan perempuan sangat diperlukan dalam berteman dan bermasyarakat. Sifat perempuan yang kasar tidak identik dengan perempuan Jawa dalam segi kehidupannya dituntut untuk bersikap lembut terutama kepada orang yang lebih tua.

Sikap tunduk dan hormat yang tokoh utama perempuan lakukan kepada orang tua, suami, maupun orang lain. Karena orang Jawa sangat menghargai orang lain terutama orang yang lebih tua. Masyarakat Jawa beranggapan bahwa apabila tidak menghargai orang tua maka "pamali (tidak baik)" hukumnya. Apabila kurang menghormati, maka semua yang diperbuatnya tidak akan direstui. Sikap bakti semata-mata sebagai rasa ungkapan penghormatan terima kasih dan kasih sayang kepada orang yang lebih tua atau orang yang berpengaruh dalam hidup. Hal ini terbukti dalam kutipan dibawah ini.

Sehari dua kali, pagi dan siang, aku mengirim jatah makanan untuk Bapak di sawah. Sebenarnya, aku sangat khawatir melihat kondisi kehidupan Bapak di sawah. Sebagai perempuan, sesungguhnya aku tak sampai hati melihat Bapak tinggal di tempat seperti itu. Bapak tidur di gebeuk kecil tidak lebih besar dari ukuran kakus di kebun belakang. Dindingnya compang-camping, karena lapisannya yang berasal dari berbagai plastik yang ditambal sana sini agar air hujan tak merembes masuk ke dalam. (HS: hal 59)

Kutipan di atas menunjukkan rasa bakti dan kasih sayang yang dilakukan oleh Sayem terhadap Bapak. Bapak yang saat itu lebih memilih untuk pergi dari rumah dan lebih memilih untuk tinggal di gubuk kecil tengah sawah sendirian. Sayem rela mengantarkan bekal makan pagi, siang, dan sore untuk Bapak. Hal tersebut supaya Bapak tidak kelaparan disaat semua keluarganya tidak ada di sampingnya. Ketika Bapak telah meninggal, Sayem masih berbakti kepadanya. Bakti tersebut ia buktikan dalam wasiat perjodohan yang diungkapkan bapak sebelum meninggal.

Setelah Bapak meninggal dunia dan Ibu meninggalkan rumah, Sayem hanya memiliki Simbah yang merawatnya dari kecil. Simbah sangat berarti baginya. Saat ia dijodohkan di usianya tepat 12 tahun atas keinginan Simbah, ia tidak bisa berbuat apa pun. Sayem telah menolak dengan berbagai pendapatnya bahwa ia belum siap menikah, namun Simbah tidak menghiraukan pendapat Sayem tersebut. Setelah semuanya selesai, Sayem menjalani hidupnya dengan bekerja serabutan seadanya. Motivasi Sayem dalam bekerja pun karena Simbah. Ia tidak ingin mengecewakan Simbah. Ia merasa harus semakin berbakti kepada Simbah. Berikut kutipannya.

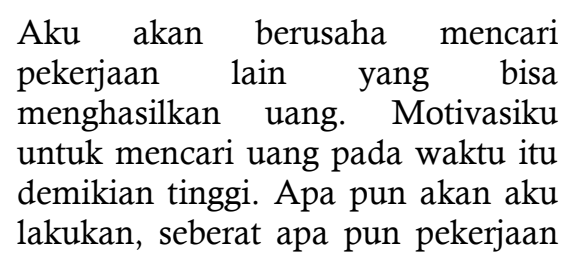


itu akan aku terima, asal bisa menghasilkan uang. (HS: hal 167)

Kutipan di atas menunjukkan bahwa Sayem tidak ingin mengecewakan Simbah lagi atas penolakan perjodohan pertamanya. Ia berusaha membuat Simbah selalu bahagia. Baktinya tersebut ia lakukan berbagai cara walaupun tenaga, waktu dan masa mudanya kurang menikmati. Hanya Simbah orang tua yang Sayem miliki. Simbah telah menjadi salah satu orang yang berharga setelah Kang Weng dan Sugi adiknya.

Dari hasil analisis yang dilakukan peneliti, terdapat bentuk citra perempuan Jawa dari data yang diperoleh. citra perempuan merupakan wujud gambaran mental spiritual dan tingkah laku keseharian yang terekspresi oleh perempuan dalam berbagai aspeknya yaitu aspek fisis dan psikis sebagai citra diri perempuan serta aspek keluarga dan masyarakat sebagai citra sosial. Jadi, citra perempuan merupakan gambaran tentang sikap mental maupun perilaku perempuan dalam kesehariannya.

Hal yang paling menonjol dari bentuk citra perempuan Jawa adalah ketika Sayem ingin membentuk citranya sebagai perempuan Jawa di dalam masyarakat. Citra tersebut dijadikan pondasi atau patokannya dalam bertindak. Citra demikian timbul karena adanya konsep gender yakni suatu sifat yang melekat pada laki-laki dan perempuan yang dikonstruksi secara sosial dan kultural melalui proses panjang, sosialisasi gender tersebut akhirnya dianggap sebagai ketentuan Tuhan.

\section{Upaya Tokoh Utama Perempuan Mempertahankan Citra Perempuan Jawa}

Dalam mempertahankan citra perempuan Jawa, tokoh utama perempuan untuk menyetarakan kedudukan antara laki-laki dan perempuan di dalam masyarakat. Berbagai upaya tokoh utama mempertahankan citra perempuan Jawa yang telah dimiliki Sayem supaya mampu bersosialisasi di masyarakat dengan baik. Tokoh perempuan melawan anggapan masyarakat di tengah kehidupan jawa yang melingkupinya.

Masyarakat di desa menganggap bahwa ketika seorang perempuan sudah mengalami masa pendewasaan maka harus segera dinikahkan. Hal ini supaya membantu perekonomian keluarga dan di jauhkan dari perbuatan zina maupun hal-hal yang tidak baik di dalam masyarakat. Namun, pernikahan tersebut tanpa mempedulikan kesanggupan dari perempuan desa untuk dinikahkan atau tidak. Semua terjadi atas kehendak kedua orang tua masing-masing. Seperti halnya Sayem, haknya sebagai perempuan untuk menolak perkawinan dini tidak ditanggapi oleh keluarga. Hal ini terbukti pada kutipan berikut.

Anggapan tentang perempuan desa yang beranjak dewasa harus segera dikawinkan agar hidupnya tidak merepotkan keluarga, menjadi tragedi terburuk dalam kehidupan perempuan di desa. Perkawinan yang di dasari pada pemenuhan materi, seperti apa yang telah dilakukan Simbah, bisa berakibat buruk. Simbah sama sekali tidak memedulikan kondisiku yang secara biologis belum siap untuk memasuki wilayah itu. Aku belum memasuki masa haid, 
sebab umurku baru 12 tahun. Itu pun juga tidak menjadi pertimbangan Simbah. (HS: hal 149)

Kutipan tersebut menegaskan bahwa adanya menyetarakan hak perempuan terutama perempuan Jawa di desa. Masyarakat desa memilih untuk menikahkan anak perempuannya untuk menyetabilkan perekonomin keluarga tanpa memerdulikan kesanggupan perempuan untuk dinikahkan di bawah umur. Sayem berusaha melawan anggapan perempuan desa dalam masyarakat tersebut dari belenggu patriarki yang melingkupinya.

Tokoh utama perempuan merasa segala pendapat dan berbagai haknya tidak ada yang menanggapinya. Ia merasa haknya sebagai perempuan di dalam keluarga tidak ada artinya.

Dibuktikan dalam kutipan berikut.

\begin{abstract}
Mengapa tidak semua orang mengerti hati perempuan? Mengapa tidak ada orang yang mau memahami keputusanku? Tak ada kata-kata yang keluar dari mulutku untuk mengatakan ya atau tidak atas nasihat kakangku. (HS: hal 153)
\end{abstract}

Dari kutipan tersebut, terlihat bahwa segala sesuatu yang dikatakan Sayem tidak ada yang menanggapinya. Ia merasa tidak ada yang mau mengerti hati perempuan di dalam keluarganya. Semua orang di keluarga menyudutkannya karena ia memilih berpisah dengan suami pertamanya yang tidak sama sekali Sayem cintai. Perkawinan mereka terjadi karena perjodohan Simbah dan dari wasiat Bapak Sayem sebelum meninggal.

Setelah perkawinan pertamanya gagal, Sayem menjalani hidupnya dengan bekerja membantu perekonomian keluarga. Hingga usia Sayem belum genap 15 tahun, Simbah telah menyiapkan pernikahan keduanya. Di pernikahan keduanya kali ini ia hanya bisa pasrah dengan semua kehendak Simbah. Setelah menikah Sayem hidup bersama mertuanya. Ada perbedaan hak jatah makanan antara perempuan dan laki-laki di dalam keluarga mertuanya tersebut. Hal ini terbukti dalam kutipan di bawah ini.

Setiap pagi, aku menanak beras dicampur dengan tiwul. Kombinasi nasi seperti itu bagiku sangat aneh, dan sekalipun aku mencoba untuk memakannya, tapi tetap saja maksimal hanya dua sampai tiga sendok makan yang tertelan. (HS: hal 182)

Laki-laki mendapat jatah berbeda. Laki-laki mendapat jatah nasi putih tanpa dicampur, itlah adat yang dianut oleh keluarga mertuaku. Laki-laki memiliki kedudukan yang lebih tinggi dibanding perempuan, sekalipun itu ibu kandung maupun istrinya sendiri. Pernah aku protes pada suami, namun aku protes bukan untuk diriku, tapi untuk anak perempuannya. Bagaimana mungkin anak yang masih kecil harus mengikuti aturan yang seperti itu? Bagiku, itu sangat tidak masuk akal dan berkesan kejam. (HS: hal 183)

Kutipan tersebut menunjukkan bahwa adanya upaya menyetarakan hak perempuan antara laki-laki. Mereka masih bersikeras bahwa hal tersebut menjadi tradisi dari nenek moyang. Namun, perbedaan jatah makan sangat tidak masuk akal bila diterapkan untuk anak kecil yang masih dalam masa pertumbuhan. Karena kandungan protein yang ada dalam beras berpengaruh dalam masa pertmbuhan. Maka, bila beras dicampur dengan tiwul akan 
mengalami penurunan kandungan rotein di dalam beras tersebut. Protes Sayem untuk meyetarakan jatah makanan supaya tidak ada ketertindasan hak perempuan lagi di dalam keluarga mertuanya itu.

- Dalam rumah itu, pegawai perempuan seakan tidak dihargai sebagai buruh dan hanya diperas tenaganya. Dalam hal apapun, buruh perempuan selalu dibedakan dengan buruh laki-laki. Sayem berpikir rasional bahwa semua makhluk sama dan mempunyai kebebasan masing-masing. Ketidakadilan antara perempuan dan laki-laki di rumah tersebut semata-mata supaya uang yang di dapatkan semakin lebih banyak dibandingkan dengan pengeluaran untuk buruh perempuan di perkecil. Selain itu, mereka menganggap bahwa tenaga yang dihasilkan oleh buruh perempuan tidak sebanding dengan buruh laki-laki. Ketidakberdayaan buruh perempuan membuat ketidakadilan gender ini berlangsung lama.

Dari hasil analisis yang dilakukan peneliti, upaya tokoh utama perempuan dalam mempertahankan citra perempuan Jawa adalah menyetarakan hak perempuan, menyatakan pendapat, dan mempertahankan keutuhan rumah tangga. Dalam upaya menyetarakan hak perempuan, Sayem berusaha untuk disetarakan dengan laki-laki supaya tidak ada lagi ketidakadilan gender. Sayem menyetarakannya berdasarkan pemikiran rasional yang ada dalam dirinya. Bahwa kedudukan perempuan dan lakilaki harus disetarakan. Walaupun belenggu tradisi jawa yang masih kental diwilayahnya. Terutama tentang perempuan dan haknya. Dalam menyatakan pendapat, Perempuan dianggap tidak memiliki hak untuk bebas berpendapat. Mereka seakan diberi batasan untuk mengungkapkan pendapatnya, karena pendapat mereka dianggap tidak ada artinya Sayem telah melakukan pendobrakan sebagai perempuan Jawa. Bahwa pendapatnya sebagai perempuan memiliki kebebasan supaya perempuan tidak serta merta menyetujui atas semua yang tidak dikehendakinya. Perempuan berhak melawan dan berpendapat baik di dalam keluarga maupun dalam masyarakat.

Selain upaya menyetarakan hak perempuan dan kebebasan berpendapat, upaya tokoh utama perempuan mempertahankan citra perempuan Jawa yang terakhir adalah mempertahankan keutuhan rumah tangga. Bahwa perempuan lebih daripada laki-laki, membuat keputusan dalam pengaturan rumah tangga, dan dalam menumbuhkan suatu keluarga, sebagai panggilan pertama dalam bertindak. Perempuan juga sebagai penanggung jawab utama, bukan saja bagi pembentukan suatu keluarga, melainkan juga memelihara keluarga. Upaya Sayem dalam mempertahankan citra perempuan Jawa menjadikan sosok Sayem sebagai perempuan yang mampu bertahan dalam citranya demi anak. Ia berupaya mempertahankan citra perempuan Jawa di tengah-tengah masyarakat yang mengatakan bahwa perempuan tidak akan bisa hidup dimadu bersama empat istri lainnya. Ia tetap bertahan dalam keutuhan rumah tangganya.

\section{PENUTUP}

Berdasarkan hasil analisis di atas, dapat disimpulkan bahwa novel Hati Sinden karya Dwi Rahyuningsih menggambarkan citra 
perempuan Jawa pada tokoh utama perempuan. kriteria perempuan Jawa sangat kental dengan berbagai sifat yang mampu menjadikan Sayem sebagai sosok perempuan yang nrima, sabar, pasrah, lembut, bakti, dan pandai berhemat. Selain itu, Sayem juga memiliki perhatian terhadap orang lain dan pengendalian diri tinggi sehingga ia tidak menyukai konflik yang menurutnya sangat tidak penting bila samasama dihadapi dengan emosi. Citra perempuan Jawa yang ia terapkan berasal dari lingkungannya yang mengajarkan berbagai citra perempuan. Sehingga, ia menjadi sosok perempuan yang memilki citra perempuan yang baik. Dalam upaya mempertahankan citra perempuan Jawa, bahwa kehidupan Sayem dalam masyarakat juga mempengaruhi citra perempuannya. tokoh utama perempuan mempertahankan citra perempuan Jawa dalam novel ini sebagai upaya menyetarakan kedudukan antara laki-laki dan perempuan di dalam masyarakat. Selain di masyarakat, Sayem mempertahankan berbagai citra perempuan sebagai upaya menyetarakan hak, menyatakan pendapat, dan mempertahankan keutuhan rumah tangganya. Upayanya tersebut menjadikan Sayem sebagai sosok perempuan yang kuat dan tindakannya sebagai perempuan sangat maksimal. Ia berusaha sekuat tenaganya untuk mempertahankan berbagai upaya. Tindakan Sayem dalam mempertahankan citra perempuan Jawa merupakan salah satu upaya untuk menyetarakan perempuan di dalam ruang lingkup masyarakat Jawa.

\section{DAFTAR PUSTAKA}

Agustin, Riska Mega. 2013. Kajian Tokoh Utama Novel Hati Sinden Karya Dwi Rahyuningsih Pendekatan Psikologi Sastra. Tesis.
Fakultas Keguruan dan Ilmu Pendidikan. Bengkulu: Universitas Bengkulu.

Bell, Karen. 2016. Bread and Roses: A Gender Perspective on Environmental Justice and Public Health (Roti dan Mawar: Perspektif Gender tentang keadilan Lingkungan dan Kesehatan Masyarakat). Jurnal Internasional dari Penelitian Lingkungan. Ukraina: Bristol University.

Fraser, Nancy. 2007. Feminist Politics in the Age of Recognition: A Two-Dimensional Approach to Gender Justice (Politik feminis di Era Pengakuan: Pendekatan Dua Dimensi terhadap Keadilan Gender). Jurnal internasional dari penelitian sosial. Vol. 1 No. 1 Tahun 2007. Amerika Serikat: New School for Social Research.

Handayani, Christina S., dan Novianto Ardhian. 2004. Kuasa Perempuan Jawa. Yogyakarta: LKiS Pelangi Aksara.

Mandrastuty, Rany. 2010. Novel Tarian Bumi Karya Oka Rusmini: Kajian Feminisme. Skripsi. Surakarta: Universitas Sebelas Maret.

Nurhayati. 2014. Citra Perempuan dalam Novel Perempuan Berkalung Sorban Karya Abidah El-Khalieq. Jurnal Pendidikan Bahasa dan Sastra Indonesia. Vol. 1 No. 2 tahun 2014. Purwokerto: Universitas Muhammadiyah.

Rahyuningsih, Dwi. 2011. Hati Sinden The Hidden Sides Of Sinden. Yogyakarta: Diva Press.

Rejeki, Sri Kartina. 2013. Citra Perempuan Jawa Dalam Cerbung Teratai Wungu Karya Ibne Damayant (Kajian Kritik Sastra Feminis). Skripsi. Yogyakarta: Universitas Negeri Yogyakarta.

Rini, Ajeng Mega Listia. 2014. Citra Perempuan pada Novel Hati Sinden Karya Dwi Rahyuningsih (Kajian Feminisme Marxis). Skripsi. Pontianak: Universitas Tanjungpura. 
Susanto, Dwi. 2016. Pengantar Kajian Sastra. Yogyakarta: CAPS (Certer for Academic Publishing Service).

Yeni, Syafrima. 2013. Fenomena Feminisme dalam Novel Cinta Suci Zahrana Karya Habiburahman El Shirazy. Jurnal Pendidikan Bahasa dan Sastra Indonesia. Vol. 1 No. 2 Maret 2013. Padang: Universitas Negeri Padang.

Yuliastuti, Fitri. 2005. Citra Perempuan alam Novel Hayuri Karya Maria Etty. Skripsi. Fakultas Sastra dan Seni Rupa. Surakarta: Universitas Sebelas Maret. 